\title{
Epstein-Barr Virus Analysis Method
}

National Cancer Institute

\section{Source}

National Cancer Institute. Epstein-Barr Virus Analysis Method. NCI Thesaurus. Code C158882.

A request to enter the specific molecular analysis method used to detect Epstein-Barr Virus. 